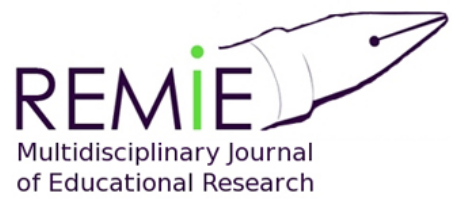

Instructions for authors, subscriptions and further details:

http://remie.hipatiapress.com

\title{
Iranian EFL Teachers' Emotional Intelligence and their Use of Speaking Strategies
}

Karim Shabani ${ }^{1}$ Arezu Ghodrati ${ }^{1}$

1) Allameh Mohaddes Nouri University, Islamic Republic of Iran

Date of publication: June $15^{\text {th }}, 2018$

Edition period: June 2018-October 2018

To cite this article: Shabani, K. \& Ghodrati, A. (2018). Iranian EFL Teachers' Emotional Intelligence and their Use of Speaking Strategies. Multidisciplinary Journal of Educational Research, 8(2), 146-179. doi: 10.17583/remie.2018.3450

To link this article: http://dx.doi.org/10.17583/remie.2018.3450

PLEASE SCROLL DOWN FOR ARTICLE

The terms and conditions of use are related to the Open Journal System and to Creative Commons Attribution License (CC-BY). 


\section{Iranian EFL Teachers' Emotional Intelligence and their Use of Speaking Strategies}

Karim Shabani

Allameh Mohaddes Nouri

University
Arezu Ghodrati

Allameh Mohaddes Nouri

University

\section{Abstract}

The study was designed to investigate the differences among Iranian EFL teachers in terms of emotional intelligence (EI) and their use of speaking strategies. To this end, 90 EFL male and female teachers teaching English at 9 institutes in Behshahr, Sari, and Amol cities in Mazandaran Province (north of Iran) were randomly selected. The research data were collected through the Bar-On EQ-I scale and teachers' use of speaking strategies questionnaire. Results on Independent Sample ttest reported significant differences in teachers' EI across gender. One-way ANOVA revealed differences in teachers' EI across years of teaching experience. Furthermore, results on Kruskal Wallis Test indicated differences in teachers' use of each speaking strategy regarding their level of EI. Based on the findings, teachers with a higher level of EI preferred to focus on both accuracy and fluency and apply story-telling activities to create more successful interaction. While teachers with a lower level of EI preferred to focus on accuracy, they liked to apply information-gap activities. They preferred to offer implicit feedback through reformulation and tended to design groups and pairs to make silent students interact in the classroom. Moreover, both groups preferred to correct their learners later.

Keywords: teachers' emotional intelligence (EI), feedback, speaking strategies 


\section{Inteligencia Emocional de Maestros de EFL Iraníes y su Uso de Estrategias de Habla}

Karim Shabani

Allameh Mohaddes Nouri

University
Arezu Ghodrati

Allameh Mohaddes Nouri

University

\section{Resumen}

El estudio investiga las diferencias entre los profesores de EFL iraníes en términos de inteligencia emocional (EI) y su uso de estrategias de oratoria. Con este fin, se seleccionó aleatoriamente a 90 profesores y maestras de EFL que enseñaban inglés en 9 institutos en las ciudades de Behshahr, Sari y Amol en la provincia de Mazandaran (norte de Irán). Los datos de la investigación se recopilaron a través de la escala Bar-On EQ-I y el cuestionario de estrategias de uso del docente. Los resultados de la prueba $\mathrm{t}$ de muestras independientes informaron diferencias significativas en la IE de los docentes en todos los géneros. ANOVA de un factor reveló diferencias en EI de docentes a través de años de experiencia docente. Además, los resultados en la prueba de Kruskal-Wallis indicaron diferencias en el uso por parte de los docentes de cada estrategia de habla con respecto a su nivel de EI. Con base en los hallazgos, los maestros con un mayor nivel de EI prefirieron enfocarse tanto en la precisión como en la fluidez y aplicar actividades de narración de historias para crear una interacción más exitosa. Profesores con un nivel más bajo de IE prefirieron centrarse en la precisión, aplicando actividades de brecha de información. Preferían ofrecer retroalimentación implícita a través de la reformulación y tendían a diseñar grupos y pares para hacer que los estudiantes silenciosos interactuaran en el aula. Además, ambos grupos prefirieron corregir a sus alumnos más tarde.

Palabras clave: graduate education, science, scientific literacy, STS 
$\mathrm{P}$ revious studies suggest that teachers make a difference in the lives of students both academically and personally. According to Veen et al. (2005, cited in Thoonen et al., 2011) teachers' personal and psychological factors are the key elements affecting their teaching and learning. One approach to exploring the emotional practice of teaching involves understanding the "emotional intelligence" (EI) performed by teachers at work. EI was described by Bar-On (2002) as "an array of noncognitive capabilities, competencies, and skills that influence one's ability to succeed in coping with environmental demands and pressures" (p.14). It is considered to be more powerful than IQ in predicting success in life challenges, in distinguishing successful people within job categories or profession (Goleman, 1995). Teachers' emotional skills have recently received considerable research interest in the field of education and psychology. Previous researches demonstrated that emotional intelligence is associated with success in many areas, including effective teaching (Ghanizadeh \& Moafian, 2010), student learning (Brackett \& Mayer, 2003), and academic performance (Gil-Olarte, Palomera, \& Brackett, 2006). With this information at hand, the context of foreign language teaching with regard to the personality factors of EFL teachers remains challengeable and needs more practical study and investigation.

Among the four language skills, speaking is viewed to be the most important skill of all the four skills (listening, speaking, reading, and writing) because people who know a language are usually referred to as speakers of that language (Ur, 2005). Teachers play an essential role in the acquisition of this skill in that they are in charge of promoting meaningful communication in the classroom. As speaking is an important medium of providing input for learners of English, finding optimum ways of teaching speaking is a challenging task for EFL teachers and researchers. Since teachers are different in emotional intelligence and other personality traits, they may choose different speaking strategies. Being aware of such personality factors might help them select the best way of speaking strategies.

The present study was an attempt to investigate the differences in Iranian EFL teachers' EI and their use of speaking strategies. In order to explore the 
differences in these two constructs, it is necessary to review the related literature and the previous studies on the topic.

\section{Related Studies}

The related literature on EI and teaching speaking will be reviewed in the following sections.

\subsection{Emotional Intelligence}

1.1.1. Theoretical framework of emotional intelligence. Various theories exist under the term intelligence. The concept of social intelligence was born through attempts by Thorndike in 1920. He defined the term as the ability to understand men and women, boys and girls and to act wisely in human relations (Mayer \& Salovey, 1997). David Weschler (1940), the father of IQ (general intelligence), discussed the idea of there being nonintellective aspects to intelligence. Maslow (1950) describes how people can build emotional strength. Leuner (1966) was then the first individual to link EI to psychotherapy treatments. Howard Gardner (1983) published a study on multiple intelligences. His concepts of interpersonal intelligence (the ability to understand other individuals' emotions and intentions) and intrapersonal intelligence (the ability to know one's own emotions) are widely regarded as the basis for conceptualizing EI. Bar-On (1985) coined the term 'Emotional Quotient' to describe his approach to assessing emotional intelligence. However, it was the work by Peter Salovey and Jack Mayer (1990) that produced the first theory on EI. The EI concept was then made popular through Daniel Goleman's book published in 1995.

According to Mayer and Salovey (1997), emotional intelligence consists of two parts as emotion and intelligence. Emotions refer to the feelingreactions a person has, often in response to a real or imagined relationship. For example, if a person has a good relationship with someone else, that individual is likely to feel happy; if the person is threatened, he or she will be likely to feel afraid. Intelligence, on the other hand, refers to the ability to reason validly with or about something. For example, one reason with 
language in the case of verbal intelligence, or reasons about how objects fit together in the case of spatial intelligence.

\subsubsection{Various views and definitions of Emotional Intelligence.} Salovey \& Mayer (1990, p. 189) defined the term EI as "a form of social intelligence that involves the ability to monitor one's own and others feelings and emotions to discriminate among them and use this information to guide one's thinking and action." They further propose that "Emotional intelligence involves the ability to perceive accurately, appraise, and express emotion; the ability to access and/or generate feelings when they facilitate thought; the ability to understand emotion and emotional knowledge; and the ability to regulate emotions to promote emotional and intellectual growth.” (Mayer \& Salovey, 1997, p. 10).

Bar-On (1997a, p. 14) defined EI "as an array of non-cognitive capabilities, competencies and skills that influence ones' abilities to succeed in coping with environmental demands and pressures". Goleman (1998) defined EI as the capacity to recognize our own feelings and those of others, for motivating ourselves, and for managing emotions well in ourselves and in our relationships.

1.1.3. Models of Emotional Intelligence. Roohani (2009) mentioned that emotional intelligence can be investigated in two ways: ability models and mixed models. Ability model refers to emotional intelligence as a pure form of mental ability and also as a pure intelligence. On the other hand, the proponents of mixed model expanded the meaning of EI by combining cognitive ability with personality traits.

Mayer and Salovey (1997) proposed an ability model with a two-part form, speaking first of the general processing of emotional information, and secondly specifying the skills involved in such processing (Motallebzadeh, 2009). The model comprises four abilities: perception, assimilation, understanding, and regulation of emotions. Concisely, emotional perception consists of the ability to perceive emotions on the self and on the others, and also on objects, art, stories, music, and other stimuli. The assimilation of emotions is the ability to generate, use, and feel emotions as necessary to communicate feelings, or to use them in other cognitive processes. 
Emotional understanding is related to the ability to understand emotional information, how emotions combine and shift across time, and the ability to appreciate emotional meanings. Finally, emotional regulation refers to the ability to stay open to feelings, and to monitor and regulate one's and other's emotions to promote understanding and personal growth. These four branches are hierarchically organized, thus, perceiving emotions is at the most basic level, and managing emotions is at the highest and most complex level in the hierarchy; therefore, the ability to regulate one's and other's emotions is built on the basis of the competencies of the three other branches.

Two mixed models of EI were introduced by Goleman and Bar-on. They defined emotional intelligence in a different way. Goleman (1998) described a mixed model in terms of performance, individual abilities and competencies, integrating personality trait and employing their similar effects on performance in the workplace. While Bar-On's (1985) model provided personality basis, emphasizing the co-dependence of the ability aspects of emotional intelligence with personality traits and their application to personal wellbeing (Nassimi, 2009).

Goleman (1998) stated that EI comprises five essential elements: 1) knowing one's emotions; 2) managing emotions; 3) motivating oneself; 4) recognizing emotions in others, and 5) handling relationships. But in 1998 his model presents 4 essential dimensions and 20 competencies (Goleman, 1998). First, self-awareness is the ability to be conscious and appreciate one's feelings and includes 3 competencies: emotional self-awareness, accurate self-management, and self-confidence. Second, self-Management is the ability to effectively manage one's emotions and comprises 6 competencies: self-control, trustworthiness, conscientiousness, adaptability, achievement drive and initiative. Third, social awareness is the ability to associate with and feel part of one's social group and includes 3 competencies: empathy, service orientation, and organizational awareness. Fourth, relationship management is the ability to appreciate and affect others' emotions and includes 8 competencies: developing others, influence, communication, conflict management, leadership, change catalyst, building bonds and teamwork and collaboration. 
Bar-On (1997b) coined the term 'emotional quotient' (EQ). Based on Bar-On's model of EI, EI is a combination of emotional and social skills that determine our understanding and expression of ourselves, our understanding for others and interaction with them, and the ability to deal with daily necessities and problems. His inventory measures 5 major scales and 15 subscales:

1) Intrapersonal skills refer to the ability to know and control one's emotions. It comprises emotional self-awareness (the ability to be aware, recognize and understand feelings and ideas in the self), assertiveness (the ability to express and defend beliefs and thoughts in the self), self-regard (the ability to understand, accept and respect of the self), self-actualization (the ability to realize one's potential), independence (the ability to be self-controlled and self-directed in ones thinking and free from emotional dependency).

2) Interpersonal skills refer to the ability to be aware of and understand feelings and ideas in the others. It involves empathy (the ability to understand how others feel and appreciate others feelings), interpersonal relationship (the ability to establish and maintain mutually satisfying relationships that are characterized by emotional closeness and intimacy and by giving and receiving affection), social responsibility (the ability to demonstrate oneself as a cooperative, constructive and responsible member of the society).

3) Adaptability is concerned with the ability to adjust to change. It includes reality-testing (the ability to assess between what is subjectively experienced and what objectively exists), problem solving (the ability to identify and solve the problem) and flexibility (the ability to adapt one's emotions and thoughts to change).

4) Stress management refers to manage and regulate emotions and control stress. It comprises stress tolerance (the ability to cope with stressful situations by managing emotions) and impulse control (the ability to delay a desire or temptation by controlling one's emotion). 
5) General mood is concerned with the ability to be optimistic and enjoy life. It includes happiness (the ability to be satisfied and enjoy life) and optimism (the ability to think positively and keep a positive attitude in the face of difficulties).

\subsection{Teaching Speaking}

Speaking is a productive oral skill which is the hardest skill to teach because it happens in real time (Nunan, 2003). Celce-Murcia (2003) argued that for most people "the ability to speak a language is synonymous with knowing that language since speech is the most basic means of human communication." (p.103). Learners' success in language learning is by their feeling about their progression in language proficiency. To achieve this goal, teachers and materials for teaching speaking must provide the strategies that are necessary for developing good speaking abilities.

1.2.1. Aspects of speaking. In teaching speaking skills, teachers should consider two aspects, namely fluency and accuracy. Therefore, when they teach speaking to their students, neither of these two elements should be neglected. The absence of either of these elements will create ambiguity and impatience on the part of the listener.

1.2.1.1. Fluency. Fluency usually refers to expressing the oral language freely without interruption. According to Hedge (2000, p. 261), fluency means responding coherently with the turns of the conversation, linking words and phrases using intelligible pronunciation and appropriate intonation, and doing all this without undue hesitation. To achieve this goal, the teachers should allow learners to use their personal language freely to express their own ideas without interruption.

1.2.1.2. Accuracy. Accuracy is the ability to produce grammatically correct sentences and it focuses on the correct use of grammar and vocabulary and other skills. Skehan (1996b, p.23 cited in Ellis \& Barkhuizen, 2005, p.139) defines accuracy as "how well the target language is produced in relation to the rule system of the target language." Therefore, 
learners should focus on a number of things in their production of the spoken language, mainly, the grammatical structure, vocabulary and pronunciation.

$>$ Pronunciation. As Redmond and Vrchota (2007, p.104) state, "It is imperative that you use the correct word in the correct instance and with the correct pronunciation. Pronunciation means to say words in ways that are generally accepted or understood." However, if the pronunciation is not correct, the speakers then will not be understood and therefore accuracy is not achieved. So, intelligibility is the most sensible goal in teaching pronunciation. Intelligibility has been defined as being understood by a listener at a given time in a given situation.

$>$ Grammar. Achieving accuracy in terms of grammar refers to the study of how words combine to form sentences (Nelson, 2001, p. 1). This is done by a set of rules or principles that can be used to generate all well-formed or grammatical utterances in the language (Purpura, 2004, p. 6).

Vocabulary.Vocabulary is a set of lexemes including single words, compound words and idioms (Richard \& Schmidt, 2002, p. 580). Accuracy in vocabulary use refers to the appropriate selection of words during speaking. The knowledge of the word classes also allows speakers to perform well-formed utterances (Harmer, 1991). Students then, have to be able to use words and expressions accurately. They sometimes use words incorrectly like in the case of synonyms which do not carry the same meaning in all contexts.

1.2.2. Speaking activities. A large number of speaking activities are used in the classroom in many circumstances. Among others, the examples of speaking activities are the discussion and debate, drama, role play, and simulation, presentation, classroom conversation, casual chat, outside-class speaking, storytelling, joke, and anecdote (Thornbury, 2005, pp. 89-110). 
Littlewood (1981, p. 47) states that "discussion provides learners with opportunities to express their own personality and experience through the foreign language". Drama, role play, and simulation activate students' imagination. Drama provides a useful springboard for real-life language use. Role-play gives students an opportunity to practice communicating in different social contexts and in different social roles. Presentation is a planned talk followed by a question session. Essberger (1998) suggests that participation could be accomplished by means of presentations. Classroom conversation is called a planned conversation to encourage the students to speak English. Outside-class speaking consists of tape diaries, video conferencing, and human-computer interaction. Storytelling is an effective tool in improving the oral competencies of students (Isbell, Sobol, Lindauer \& Lowrance, 2004). In information-gap activity, speakers have different parts of information making up a whole. Harmer (1998, p.88) argues that the teacher uses this kind of activities aiming at sharing information between students during a classroom oral course.

1.2.3. Teachers' feedback in speaking. Lynch (1996, p. 117) stated that the term feedback refers to any information that leads to the success of the message. Teachers need to help students to cope with errors by giving feedback. Feedback is a necessary element in teaching and is used throughout the lesson. Yet, the teachers may differ in using different correction strategies. According to Ellis (2008), direct or explicit feedback occurs when the teacher identifies an error and provides the correct form, while indirect or implicit feedback refers to situations when the teachers shows that an error has been made but does not provide a correction, thereby leaving the students to infer and correct it. The teachers should recognize how and when to correct their students' performance. If the teachers interrupt and correct whenever there is a problem, the conversational flow as well as the purpose of the speaking activity will be destroyed (Harmer, 2001). Group work is likely to promote collaboration among the learners, in which learners help each other and are encouraged to share their ideas and knowledge (Doff, 1991). 
1.2.4. Dealing with silent students. While speaking class demands active participation of the students, some of them are silent during the lesson. Teachers should consider the class situation and choose an appropriate way to make silent students interact in the classroom. As admitted by researchers, teachers can design pair/group work or they can choose interesting topics. Ur (1996, pp.5-6) claims that in order to get the pupils to communicate with each other and express themselves freely in the target language it is necessary to use interesting topics, but more importantly the discourse must have a meaningful purpose. Participation in communicative activities such as paired and small group activities would enhance meaningful and interesting interactions as well as provide more opportunities to speak (Scarcella \& Oxford, 1992).

\subsection{Studies on Emotional Intelligence and Teaching Speaking}

To confirm the relationship between EFL teachers' emotional intelligence and job satisfaction, Hekmatzadeh, Khojasteh and Shokrpour (2016) asked EFL teachers who work at private language institutes in Iran to complete the Bar-On questionnaire and a modified version of Karavas's (2010) job satisfaction scale. Subsequent to feeding the data into SPSS and running Pearson Product-Moment Correlations, these researchers found a positive and significant relationship between EFL teachers' emotional intelligence and job satisfaction. Furthermore, significant differences in emotional intelligence between EFL male and female teachers (but not a significant correlation between EFL teachers job satisfaction in terms of gender) were found.

Mousapour and Khorram (2015) found a significant correlation between Iranian EFL teachers' scores on emotional intelligence and teaching styles. The participants of this study were 90 Iranian EFL teachers from Sistan and Baluchestan's high schools and language institutes from whom the data were collected through the use of Bar-On Emotional Quotient questionnaire and Grasha's Teaching Styles Inventory questionnaire. It was found that among the five components of emotional intelligence, four components (interpersonal, intrapersonal, adaptability, and stress management) were positive predictors of teaching styles of EFL teachers. 
Upadhyaya (2013) examined the correlation between emotional intelligence and academic achievement among student-teachers. To assess the emotional intelligence of student-teachers, the participants were asked to complete the test of emotional intelligence of Misra. Collected data were matched with the student-teachers' marks in theory and practical examination. Based on the findings of the research, there was a positive correlation between student-teachers' emotional intelligence and academic achievement (theory and practice), i.e. the more emotionally intelligent they were the better they were found to score in theory and practical examination.

To explore the teaching of speaking in secondary education (SE) institutions and state language schools (EOI) in Spain, Alonso (2014) used a sample of all in-service teachers (from twelve secondary schools and two EOIs in Galicia) who were then administered a questionnaire focused on the time devoted to the teaching and practicing of spoken English, the assessment of speaking, the type of activities the participants used and frequency of their use. To analyze the data, a Wald-type test was run. Results of this exploratory study revealed that EOI teachers devote more time to the teaching and practice of speaking, focus more on pronunciation and interaction in the assessment of speaking, and prefer less-controlled tasks.

Anjaniputra (2013) conducted a research to identify teachers' strategies in teaching speaking to the students at the secondary level and recognize the students' response to the strategies. An English teacher and a class of 22 students involved in this study. To identify the strategies of teaching speaking, the researcher employed classroom observation and interview and to obtain the data about the students' response towards the strategies, a questionnaire was given to students. The findings indicated that the teacher applied cooperative activities, role-play, creative tasks, and drilling and the students had a positive attitude towards the strategies as they responded that the strategies helped them to speak. 


\section{The Present Study}

Following the model proposed by Bar-On (1985), the present study was intended, first, to determine the differences in teachers' EI across gender and years of teaching experience. Then, differences in teachers' use of each speaking strategies with respect to their level of EI were explored. Hence, the following research questions were raised:

1. Is there any significant difference among Iranian EFL teachers in terms of EI across gender?

2. Is there any significant difference among Iranian EFL teachers in terms of EI with respect to years of teaching experience?

3. Is there any significant difference among Iranian EFL teachers with different EIs in the use of speaking strategy?

\section{Methodology}

\subsection{Research Design}

The design of this study was a descriptive field study. Heppner, Kivlighan, and Wampold (1999) portray these studies as "investigations that do not exercise experimental control (randomization, manipulation of variables) and are conducted in a real life setting" (p.48). Due to the nature of the design, the present study was high in external validity since participants were directly recruited from the population of interest. All the participants were chosen randomly. In this research, teachers' EI served as an independent variable and their use of speaking strategies served as the dependent variable. 
REMIE - Multidisciplinary Journal of Educational Research, 8(2) 159

\subsection{Participants}

The present study was conducted with the participation of 90 (50 female and 40 male) EFL teachers with teaching experiences ranging from 1 to 15 years. Teachers held either BA $(n=56)$ or MA $(n=34)$ degrees. Besides, teachers ranged in age from 20 to 50 years. The summary of the participants' specifications is shown in tables 1 and 2 below.

Table 1:

\begin{tabular}{lll}
\multicolumn{3}{l}{ Distribution of subjects based on gender } \\
\hline Gender & Frequency & Percent \\
\hline Male & 40 & 44.4 \\
Female & 50 & 55.6 \\
\hline Total & 90 & 100.0 \\
\hline
\end{tabular}

Table 2.

Distribution of subjects based on years of experience

\begin{tabular}{ccc}
\hline $\begin{array}{c}\text { Years of } \\
\text { experience }\end{array}$ & Frequency & Percent \\
\hline $1-5$ & 29 & 32.2 \\
$6-10$ & 30 & 33.3 \\
$11-15$ & 31 & 34.4 \\
\hline Total & 90 & 100.0 \\
\hline
\end{tabular}

\subsection{Instrumentation}

To obtain the relevant data, the researcher employed two sets of instruments as follows: 

a. Bar-On EQ test (to measure the teachers' level of emotional intelligence)

b. Teachers' use of speaking strategies questionnaire (to get an understanding of the teachers' use of speaking strategies)

3.3.1. Bar-On EI test. Bar-On EI test is a self-report measure of emotionally and socially intelligent behavior that provides an estimate of emotional-social intelligence (Bar-On, 1985). It is also called the emotional quotient inventory (EQ-I) designed by Bar-On in 1980. Though the original version of the test included 133 items, later revisions were applied to the test by Bar-On himself (1985) who reduced its size to a considerable degree so that the modified version of the test comprised only 117 items. It is suitable for individuals with 17 years of age and older. To avoid cross-cultural differences and probable misunderstanding regarding the context of the questionnaire, the translated Persian version of this questionnaire was developed by Samouei (2002) and reduced into 90 items in the form of short sentences which measure five broad areas of skills and 15 factorial components (already explained in Bar-On's model). Each item employs a five point Likert scale with a textual response format ranging from strongly disagree (1) to strongly agree (5). The sum of all items comprises the total score being referred to as the EQ score. The minimum score is 270 and the maximum score is 450 . In the case that some items were negatively ordered they were scored reversely. It takes approximately 40 minutes to complete the Persian version of this questionnaire.

3.3.1.1. Reliability and validity of the $E Q-i$. Reliability relates to the extent to which an instrument accurately measures a phenomenon with different groups of participants at various times (Creswell, 1994). Validity relates to the extent to which an instrument measures what it is designed to measure (Creswell, 1994). The EQ-i was found to have sufficient validity in measuring EQ. Because the EQ-I is the first empirically constructed test of non-cognitive intelligence to be published, it can be used in research such as the present study with a reasonable certainty of obtaining meaningful results. 
The reliability of the EQ items has been demonstrated in several ways; for example, the Cronbach's alpha reliability index was reported as 0.80 (Samouei, 2003). In another study, the Persian version of the questionnaire had proven to have good internal consistency, test-retest reliability and construct validity by Dehshiri (2003). The Cronbach's alpha coefficient for this measure was found to be 0.76 . Moreover, the factor analysis provided some support for the inventory's hypothesized structure. The Persian version of the questionnaire which had been proven to be valid by Dehshiri (2003) was applied in this study. In the present study, the reliability of the questionnaire was computed through Cronbach's alpha. The results show an acceptable reliability index of 0.95 for the questionnaire. As for validation, exploratory factor analysis was run.

3.3.2. Teachers' use of speaking strategies questionnaire. To find out what speaking strategies are used by teachers in their teaching of English as a Foreign Language, the researcher used a questionnaire adapted from Khadidja (2010). In order to test the validity of questionnaire as a research instrument, and hence the reliability of the data to be obtained, the questionnaire was first piloted with 60 (30 females and 30 males) EFL teachers. They were chosen randomly. Upon receiving their suggestions, some items were eliminated and others introduced. The final questionnaire was composed of five items. Each item has one orientation.

The objective of the first item is to obtain information from teachers concerning the main speaking aspects they usually focus on in classroom interaction, i.e. fluency, accuracy or both because these are also the main objectives behind teaching speaking. The second item concerns the speaking activities (including: presentation, information-gap activities, role-play, story-telling, group/pair work, and discussion) teachers focus on most to create a successful interaction. The third item is designed to get teachers' opinion on when to correct the students' mistakes during the interaction activities. The options include whether teachers prefer to interrupt their students to correct them, correct them later, ask other students to correct each other, or do not correct them at all. The fourth item is designed to get teachers' opinion on whether they use implicit or explicit feedback in giving corrective feedback to students. The fifth item designed to get information 
about the teachers' decisions to push silent students to interact in the classroom on whether they prefer to design groups and pairs or choose interesting topics.

\subsection{Data Collection Procedure}

In order to achieve the purpose of the present study, the following two phases were considered. In the first phase, permission of authorities was obtained to collect the data. In the second phase, Bar-On EQ-i questionnaire (Bar-On, 1985) and teachers' use of speaking strategies scale were given (in person) to 90 EFL teachers teaching English at 9 institutes in Behshahr, Sari and Amol cities in Mazandaran province (North of Iran). They were selected on the basis of random sampling. The purpose of the study was explained to them. The researchers assured them that the collected information would be kept confidential and used just for research purposes. Teachers took the questionnaires home, filled them out, and then returned them the following session.

\subsection{Data Analysis}

After collecting the data, EQ questionnaires were first scored based on the guidelines provided by Bar-On (1985). Then, EFL teachers' EI scores were divided into two categories of high $(n=45)$ and low $(n=45)$ by means of the software SPSS (to find the differences in teachers' EI and their use of speaking strategies).

According to the research questions mentioned before, the following statistical analyses were run using SPSS 0.23.

Independent samples t-test was run to find the differences in teachers' EI across gender. To compare two groups (for example, men and women), we computed the t-test (Dornyei, 2007)

One-way ANOVA was used to explore the differences in teachers' EI across years of teaching experience. According to Dornyei (2007), the analysis of variance (ANOVA) can be used to compare more than two groups. 
Kruskal Wallis test was run to find out the differences in teachers' use of each speaking strategy regarding their level of EI. As Dornyei (2007) states, Kruskal Wallis test is the non-parametric alternative to one-way ANOVA.

In the current study:

Runs Test was used to show that the data were selected randomly.

Levene's Test was run to indicate the equality of variances.

Shapiro-Wilk goodness-of-fit test was calculated to report the normality distribution of the data.

\section{RESULTS}

Based on the analyzed data the following results are presented to answer the research questions.

\subsection{Findings Obtained for Research Question One}

Q1: Is there any significant difference among Iranian EFL teachers in terms of EI across gender?

In order to show the differences in teachers' EI across gender, Independent samples t-test was computed.

4.1.1. The assumption for random data collection. Run test was conducted to show that the data were collected randomly. As shown in Table 3, p-values are not more than .05 for two constructs (EI and speaking strategies). So it can be concluded that the data were collected randomly and the first assumption was met. 
Table 3.

Results on Runs Test of Total EQ and speaking strategies

\begin{tabular}{ccc}
\hline & Total EQ & Total speaking \\
\hline Test Value $^{\text {a }}$ & 337.00 & 11.00 \\
Cases $<$ Test Value & 45 & 37 \\
Cases $>$ = Test Value & 45 & 53 \\
Total Cases & 90 & 90 \\
Number of Runs & 2 & 30 \\
Z & -9.329 & -3.193 \\
Asymp. Sig. (2-tailed) & .000 & .001 \\
\hline a. Median & & \\
\hline
\end{tabular}

4.1.2. The assumption for normality distribution. The results of Shapiro-wilk goodness-of-fit test showed that the total EI scores were normal in distribution $(\mathrm{p}=.85>.05$ and $\mathrm{p}=.180>.05)$. Therefore, the results of independent samples t-test were examined to find the significance of the difference (see Table 4).

Table 4.

Results on the Tests of Normality of teachers' EI across gender

\begin{tabular}{ccccc}
\hline & Gender & \multicolumn{3}{c}{ Shapiro-Wilk } \\
\cline { 3 - 5 } & & Statistic & Df & Sig. \\
\hline Total & Male & .951 & 40 & .085 \\
EQ & Female & .967 & 50 & .180 \\
\hline
\end{tabular}




\subsubsection{The assumption for equality of variances and results on} Independent sample t-test.As can be seen in Table 5, the variance came out to be homogeneous $(\mathrm{p}=.875>.05)$. In addition, according to the results obtained from independent-samples t-test of total EI scores for both males and females, there was a significant difference in teachers' EI across gender.

Results on Independent Samples t-test for differences in teachers' EI across gender

\begin{tabular}{|c|c|c|c|c|c|c|c|c|c|c|}
\hline & & \multicolumn{2}{|c|}{$\begin{array}{c}\text { Levene's Test for } \\
\text { Equality of } \\
\text { Variances } \\
\end{array}$} & \multicolumn{7}{|c|}{ t-est for Equality of Means } \\
\hline & & \multirow[t]{2}{*}{$\mathrm{F}$} & \multirow[t]{2}{*}{ Sig. } & \multirow[t]{2}{*}{$\mathrm{t}$} & \multirow[t]{2}{*}{$\mathrm{df}$} & \multirow{2}{*}{$\begin{array}{c}\text { Sig. } \\
(2- \\
\text { tailed })\end{array}$} & \multirow[t]{2}{*}{$\begin{array}{c}\text { Mean } \\
\text { Difference }\end{array}$} & \multirow{2}{*}{$\begin{array}{c}\text { Std. Error } \\
\text { Differenc } \\
\mathrm{e} \\
\end{array}$} & \multicolumn{2}{|c|}{$\begin{array}{l}95 \% \text { Confidence Interval of the } \\
\text { Difference }\end{array}$} \\
\hline & & & & & & & & & Lower & Upper \\
\hline \multirow[t]{2}{*}{ TotalEQ } & $\begin{array}{c}\text { Equal variances } \\
\text { assumed }\end{array}$ & .025 & .875 & -8.350 & 88 & .000 & -44.99500 & 5.38872 & -55.70394 & -34.28606 \\
\hline & $\begin{array}{c}\text { Equal variances } \\
\text { not assumed }\end{array}$ & & & -8.484 & 87,392 & .000 & -44.99500 & 5.30379 & -55.53620 & $-34,45380$ \\
\hline
\end{tabular}

4.1.4. Group statistics of teachers' EI across gender. The results of group statistics showed that females obtained a higher mean score than males which indicated that females are higher in EI level than males (see Table 6). 
Table 6.

Results on the group Statistics of teachers' EI across gender

\begin{tabular}{cccccc} 
& gender & $\mathrm{N}$ & Mean & Std. Deviation & Std. Error \\
& & & & Mean \\
\hline Total & male & 40 & 312.0250 & 23.35181 & 3.69225 \\
EQ & female & 50 & 357.0200 & 26.92354 & 3.80756 \\
\hline
\end{tabular}

\subsection{Findings Obtained for Research Question Two}

Q2: Is there any significant difference among Iranian EFL teachers in terms of EI with respect to years of teaching experience?

To answer this question, One-way ANOVA was run.

4.2.1. The assumption for normality distribution. The results of Shapiro-Wilk goodness-of-fit test showed that all the total EI scores were normal in distribution (see Table 7). Therefore, One-way ANOVA was used to find the differences in EFL teachers' EI across years of teaching experience. 
REMIE - Multidisciplinary Journal of Educational Research, 8(2) 167

Tabela 7.

Results on the Tests of Normality of differences in teachers' EI across years of teaching experience.

\begin{tabular}{ccccc}
\hline & $\begin{array}{c}\text { Years of teaching } \\
\text { experience }\end{array}$ & Statistic & Df & Sig. \\
\cline { 3 - 5 } & $1-5$ & .955 & 29 & .241 \\
Total & $6-10$ & .975 & 30 & .686 \\
EQ & $11-15$ & .952 & 31 & .178 \\
& & & & \\
\hline
\end{tabular}

4.2.2. The assumption for equality of variances. The results of the Levene's test (Table 8$)$ showed a significant $p$-value $(p=.725>.05)$ which showed that the assumption of equal variances was met.

Table 8.

Results on the test of homogeneity of variances of differences in teachers' EI across years of teaching experience

\begin{tabular}{cccc}
\hline Levene Statistic & \multicolumn{3}{c}{ Total EQ } \\
\cline { 2 - 4 } & df1 & df2 & Sig. \\
\hline .323 & 2 & 87 & .725 \\
\hline
\end{tabular}

4.2.3. One-way ANOVA Test: ANOVA table (Table 9) demonstrated significant statistical differences in teachers' EI across years of teaching experience $(.000<.05)$. 
Table 9.

ANOVA of differences in teachers' EI across years of teaching experience

\begin{tabular}{cccccc}
\hline & & \multicolumn{5}{c}{ Total EQ } \\
\cline { 2 - 6 } & Sum of Squares & Df & Mean Square & F & Sig. \\
\hline Between Groups & 31234.254 & 2 & 15617.127 & 19.261 & .000 \\
Within Groups & 70541.702 & 87 & 810.824 & \\
Total & 101775.956 & 89 & & \\
\hline
\end{tabular}

\subsection{Findings Obtained for Research Question Three.}

Q3: Is there any significant difference among Iranian EFL teachers with different EIs in the use of speaking strategies?

4.3.1. Inferential statistics of Kruskal-Wallis Test. Kruskal-Wallis Test was used to find if the two groups (teachers with high and low EI) were statistically different in their use of speaking strategies. The results revealed significant differences between the high- $(n=45)$ and low-EI $(n=45)$ EFL teachers in item $1(\mathrm{X} 2(1)=34.65, \mathrm{n}=90, \mathrm{p}=.000)$, item $2(\mathrm{X} 2(1)=11.62$, $\mathrm{n}=90, \mathrm{p}=.001)$, item $4(\mathrm{X} 2(1)=19.77, \mathrm{n}=90, \mathrm{p}=.000)$, and item $5(\mathrm{X} 2(1)=$ $13.11, \mathrm{n}=90, \mathrm{p}=.000)$. However, the two groups were similar in item 3 for which no significant differences were seen $(X 2(1)=2.64, n=90, p=.104)$ (see Table 10). 
REMIE - Multidisciplinary Journal of Educational Research, 8(2) 169

Table 10.

Results of the test statistics $a, b$ of differences in teachers' use of each speaking strategies regarding their level of EI

\begin{tabular}{lccccc}
\hline & Item 1 & Item 2 & Item 3 & Item 4 & Item 5 \\
\hline Chi-Square & 34.659 & 11.620 & 2.645 & 19.778 & 13.116 \\
df & 1 & 1 & 1 & 1 & 1 \\
Asymp. Sig. & .000 & .001 & .104 & .000 & .000 \\
a. Kruskal & & & & & \\
Wallis Test & & & & \\
b. Grouping & & & & \\
Variable: Total & & & & \\
EI & & & & & \\
\hline
\end{tabular}

4.3.2. Descriptive statistics of Kruskal-Wallis Test. The descriptive statistics for the first item showed a higher mean score for high-EI $(\mathrm{M}=2.57$, $\mathrm{Md}=3.00, \mathrm{SD}=.543)$ than the low-EI EFL teachers $(\mathrm{M}=1.55, \mathrm{Md}=1.00$, $\mathrm{SD}=.724$ ) indicating that the high-EI teachers tend to focus on both fluency and accuracy while the low-EI teachers tend to focus on accuracy during the classroom interaction (see Table 11).

The results of the second item showed, once more, a higher mean score for the high-EI teachers $(\mathrm{M}=4.24, \mathrm{Md}=4.00, \mathrm{SD}=1.28)$ than for their lowEI counterparts $(M=3.02, M d=2.00, S D=1.75)$ (see Table 11). It can, thus, be shown that the teachers with high EI mostly focus on story-telling activities while those with low EI focus on information-gap activities to create a successful interaction.

The results of the third item showed, however, that the teachers with low EI $(\mathrm{M}=2.15, \mathrm{Md}=2.00, \mathrm{SD}=1.24)$ had an almost as high mean score as those with high $\mathrm{EI}(\mathrm{M}=2.44, \mathrm{Md}=2.00, \mathrm{SD}=.72)$ (see Table 11). It can, therefore, be stated that both groups of teachers, equally, preferred to correct the learners' errors later.

The results of the fourth item also showed that both groups had almost similar mean scores although low-EI teachers $(\mathrm{M}=1.55, \mathrm{Md}=2.00, \mathrm{SD}=$ 
.50) had slightly higher mean than the high-EI ones $(M=1.11, M d=1.00$, $\mathrm{SD}=.31$ ) (see Table 11). The results, however, showed opposite findings. That is, the teachers with low EI tend to offer implicit corrective feedback through reformulation while the teachers with high EI tend to offer explicit corrective feedback and tell the learners about the form.

The results of the fifth item showed that the two groups were rather similar. However, the high-EI group $(\mathrm{M}=1.77, \mathrm{Md}=2.00, \mathrm{SD}=.42)$ had a bit higher mean score than the low-EI group $(\mathrm{M}=1.40, \mathrm{Md}=1.00, \mathrm{SD}=.49)$ suggesting that the teachers with high EI tended more to choose interesting topics while those with low EI tended to design groups and pairs (see Table 11).

Table 11.

Results on the Descriptive Statistics of differences in teachers' use of each speaking strategy regarding their level of EI

Percentiles

N Mean $\quad$ Std. Deviation $\quad$ Minimum $\quad$ Maximum $\quad 25^{\text {th }} \quad$ 50th (Median)

\begin{tabular}{|c|c|c|c|c|c|c|c|c|c|}
\hline \multirow{6}{*}{ High } & Item 1 & 45 & 2.5778 & .54309 & 1.00 & 3.00 & 2.0000 & 3.0000 & 3.0000 \\
\hline & Item2 & 45 & 4.2444 & 1.28197 & 2.00 & 6.00 & 3.0000 & 4.0000 & 6.0000 \\
\hline & Item 3 & 45 & 2.4444 & .72474 & 1.00 & 4.00 & 2.0000 & 2.0000 & 3.0000 \\
\hline & Item4 & 45 & 1.1111 & .31782 & 1.00 & 2.00 & 1.0000 & 1.0000 & 1.0000 \\
\hline & Item5 & 45 & 1.7778 & .42044 & 1.00 & 2.00 & 2.0000 & 2.0000 & 2.0000 \\
\hline & EQ & 45 & 1.0000 & .00000 & 1.00 & 1.00 & 1.0000 & 1.0000 & 1.0000 \\
\hline \multirow{6}{*}{ LOW } & Item 1 & 45 & 1.5556 & .72474 & 1.00 & 3.00 & 1.0000 & 1.0000 & 2.0000 \\
\hline & Item2 & 45 & 3.0222 & 1.75148 & 1.00 & 6.00 & 1.0000 & 2.0000 & 5.0000 \\
\hline & Item 3 & 45 & 2.1556 & 1.24235 & 1.00 & 4.00 & 1.0000 & 2.0000 & 3.0000 \\
\hline & Item 4 & 45 & 1.5556 & .50252 & 1.00 & 2.00 & 1.0000 & 2.0000 & 2.0000 \\
\hline & Item 5 & 45 & 1.4000 & .49543 & 1.00 & 2.00 & 1.0000 & 1.0000 & 2.0000 \\
\hline & EQ & 45 & 2.0000 & .00000 & 2.00 & 2.00 & 2.0000 & 2.0000 & 2.0000 \\
\hline
\end{tabular}


See de Figure 1.

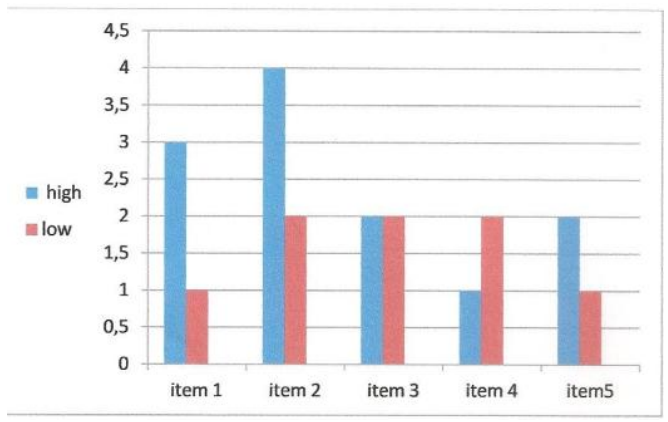

Figure 1

The median difference for the speaking scores of the teachers with high- and low-EI

\section{Discussion}

After analyzing the obtained results, a number of important points are worth mentioning. First, there were significant differences in teachers' EI across gender and years of teaching experience. It was shown that females had a higher level of EI than males and teachers with more years of teaching experience had a higher level of EI as well. Based on these results, the null hypotheses were rejected. Second, it was revealed that teachers with higher and lower EI differed from one another in their use of speaking strategies in items 1, 2, 4 and 5. As two groups were similar in item 3, no significant differences were seen. So the null hypothesis was rejected for all items, except for item 3 . In simple terms, the following outcomes were obtained for each group of teachers.

Group1: EFL teachers with a higher level of EI preferred to focus on both accuracy and fluency. To improve the students speaking skills, teachers should combine fluency and accuracy. They selected to apply story-telling activities to create more successful interaction. Moreover, using story-telling more emotionally intelligent teachers change the class room environment 
from a dry boring one to a warm environment full of students' concentration, participation and production. As Mallan (1992) reported storytelling helps develop the imagination which in turn builds on problemsolving competencies. The more teachers know about storytelling, the better they will be able to teach and model it for their students. Actually, storytelling technique attracts student's attention and higher concentration. This technique provokes prediction and expectation of events. Consequently, those effects lead to deeper comprehension, enjoyment and happiness. They tended to employ explicit corrective feedback through the expression of their opinions on the form of the mistakes and they tended to choose interesting topics to make silent learners interact in the classroom. To do this, the teacher has to think first about what is interesting for the learners rather than to him/her.

Group 2: EFL teachers with a lower level of EI preferred to focus on accuracy and they liked to apply information-gap activities. They preferred to offer implicit feedback through reformulation and they tended to design groups and pairs to make silent learners interact in the classroom.

Moreover, both groups preferred to correct their learners later and this is in line with what Harmer (1991) who stated that when students do communicative activities teachers should not interrupt them to point out a grammatical, lexical, or pronunciation error, because it can stop the communication.

The findings of the study are consistent with Ghanizadeh and Moafian (2010), and Vaezi and Fallah (2011) studies, where they found significant differences in teachers' EI across years of teaching experience. The result of the current study is in line with Hekmatzadeh, Khojasteh and Shokrpour (2016), where they reported significant differences in teachers' EI across gender.

The current study was limited to Iranian EFL teachers, not other countries with English as their EFL programs. 


\section{Conclusion}

In the present research the differences in Iranian EFL teachers' EI and their use of speaking strategies were investigated. This study provided some insights into the differences in EI as conceptualized by the Bar-On (1985) and EFL teachers' use of speaking strategies. It can be concluded that teachers' emotional intelligence is a vital concept in our era of educational climate reform. Teachers with a higher level of EI are more successful in using speaking strategies. Since emotions can be regarded as the mediators between sensory input and thinking, having a high emotional quotient may help teachers be better providers of input and they may consequently choose appropriate strategies in speaking tasks.

\section{Implications}

\subsection{Theoretical Implication}

According to Mayer \& Salovey (1997), EI is expected to be involved in the home, in school, in work, and other settings. More emotionally intelligent individuals might succeed at making their workers feel better, at communicating in interesting ways, and at designing projects that involve infusing products with feelings and aesthetics. Particularly useful, we believe, is the natural emotional teaching that comes with many of the liberal arts and with various value systems as well.

\subsection{Pedagogical Implication}

Education authorities and teacher trainers will benefit from the findings of this study to consider EI in promoting teachers with more successful teaching strategies. Language teachers will be provided with the rationale to carry out suggested strategies in class to improve students' speaking skills. 


\section{Suggestions}

Based on the obtained findings, further research is needed to replicate and expand the findings of this study by increasing the number of participants and using other instruments such as case study and interview. The following topics are worth of investigation:

- Effective ways to improve teachers' EI in EFL classrooms.

- The role of other psychological factors (e.g. personality factors or teachers' sense of self-efficacy) on EFL teachers' use of speaking strategies.

- Differences in EFL teachers' EI and their use of other English skills (listening, reading, and writing).

- The effect of explicit/ implicit corrective feedback on accuracy and fluency of Iranian EFL learners' oral production.

- The use of story-telling to improve teaching speaking in Iranian EFL context.

- The role of choosing interesting topics to make silent students interact in the classroom.

\section{References}

Alonso, R. (2014). Teaching Speaking: an Exploratory Study in Two Academic Contexts. Porta Linguarum, 22, 145-160. Retrieved from http://www.ugr.es/ portalin/articulos/PL_numero22/10\%20\%20ROSA\%2 OALONSO.pdf

Anjaniputra, A. G. (2013). Teacher's strategies in teaching speaking to students at secondary level. Journal of English and Education, [S.l.], 1(2), 1-8. Retrieved from: http://ejournal.upi.edu/index.php/LE/article/view/577 . 
Bar-On, R. (1985). The development of an operational concept of psychological well-being. Unpublished doctoral dissertation (first draft). Rhodes University, South Africa.

Bar-On, R. (1997a). The Emotional Quotient Inventory (EQ-i): A test of emotional intelligence. Toronto: Multi-Health Systems.

Bar-On, R. (1997b). Bar-On Emotional Quotient Inventory (EQ-i): Technical manual. Toronto: Multi-Health Systems.

Bar-On, R. (2002). Bar-On Emotional Quotient Inventory: Short Technical Manual. Toronto. Canada: Multi-Health Systems.

Brackett, M. A., \& Mayer, J. D. (2003). Convergent, discriminate, and incremental validity of competing measures of emotional intelligence.

Personality and Social Psychology Bulletin, 29(9), 1147-1158.

Celce-Murcia, M. (ed). (2003). Teaching English as a Second or Foreign Language (3rd Ed). Boston, MA: Heinle \& Heinle.

Creswell, J. W. (1994). Research Design: Qualitative and Quantitative Approaches. Thousand Oaks, CA: Sage.

Dehshiri, R. (2003). The Reliability and Validity of EQ-i in Iran's Context. Unpublished Master's Thesis. Allame Tabataba'i University, Tehran, Iran. Doff, A. (1991). Teach English: A Training Course for Teachers. New York: Cambridge University Press.

Dornyei, Z. (2007). Research Methods in Applied Linguistics. New York: Oxford University Press.

Ellis, R. (2008). The Study of Second Language Acquisition (2nd ed). Oxford: Oxford University Press.

Ellis, R. \& Barkhuizen, G. (2005). Analyzing Learner Language. Oxford: Oxford University Press.

Essberger, J. (1998). English speaking practice through presentation. Retrieved April, 2009 from www.englishclub.com/tefl-articles/englishspeaking-practice presentations.htm/

Gardner, H. (1983). Multiple Intelligences: The Theory in Practice. New York: Basic Books Inc.

Ghanizadeh, A., \& Moafian, F. (2010). The role of EFL teachers' emotional intelligence in their success. ELT Journal, 64(4), 424-435. doi.10.1093/elt/ccp084 
Gil-Olarte P, Palomera R, Brackett M (2006). Relating emotional intelligence to social competence and academic achievement in high school students. Psicothema, 18(suppl), 118-123. Retrieved from

http://www.psicothema.com/pdf/3286.pdf

Goleman, D. (1995). Emotional Intelligence: why it can Matter more than $I Q$. New York: Bantom Books.

Goleman, D. (1998). Working with Emotional Intelligence. New York: Bantam Books.

Harmer J. (1991). The Practice of English Language Teaching. New York: Longman Publishing.

Harmer, J. (1998). How to Teach English. Pearson Education: Longman. Harmer, J. (2001). The Practice of English Language Teaching. Harlow: Pearson Education Ltd.

Hedge, T. (2000). Teaching and Learning in the Language Classroom. Oxford: Oxford University Press.

Hekmatzadeh, M.H., Khojasteh, L. \& Shokrpour, N. (2016). Are Emotionally Intelligent EFL Teachers More Satisfied Professionally? International Journal of Applied Linguistics \& English Literature. 5(2), 97-107. doi: 10.7575 /aiac.ijalel.v.5n.2p.97

Heppner, P. P., Kivlighan, D. M., \& Wampold, B. E. (1999). Research Design in Intelligence: Kingsvillle Intelligence. Toronto, ON: MultiHealth Systems Inc.

Isbell, R., Sobol, J., Lindauer, L, \& Lowrance, A. (2004). The Effects of Storytelling and Story Reading on the Oral Language Complexity and Story Comprehension of Young Children. Early Childhood Education Journal, 32(3), 157-163. doi:10.1023.94189.a3

Karavas, E. (2010). How satisfied are Greek EFL Teachers with their Work? Investigating the Motivation and Job Satisfaction Levels of Greek EFL Teachers. Porta Linguarum, 14, 59-78.

Khadidja, K. (2010). The effect of classroom interaction on developing the learners' speaking skill. The case of third-year LMD students of English at Constantine University. Unpublished thesis. Constantine University.

Leuner, B. (1966). Emotional intelligence and emancipation. Praxis Kinderpsychol. Kinderpsychiatrie 15, 193-203. 
Littlewood, W. (1981). Communicative Language Teaching: An Introduction. New York: press syndicate of the University of Cambridge. Lynch, T. (1996). Communication in the Language Classroom. Oxford: Oxford University Press.

Mallan, K. (1992). Children as Storytellers. Portsmouth: Heinemann Educational Books, Inc.

Maslow, A. (1950). Social Theory of Motivation. Inshore, M, (Ed), Twentieth-century mental Hygiene. New-York: Social sciences publishers, 347- 357.

Mayer, J.D. \& Salovey, P. (1997). What is emotional intelligence? In P. Salovey \& D. Sluyter (Eds.). Emotional development and emotional intelligence: educational applications (pp. 3-31). New York: Basic Books.

Motallebzadeh K. (2009). The relationship between the emotional intelligence of Iranian EFL learners and their reading comprehension and structural ability. Journal of Teaching English as a Foreign Language and Literature, 1(4), 39-55.

Mousapour, G. \& Khorram, A. (2015). The relationship between Iranian EFL teachers' emotional intelligence and their teaching styles. International Journal of Research Studies in Language Learning, 4, 3-14.

Nelson, G. (2001). English an Essential Grammar. London and New York: Routledge.

Nunan, D. (ed.) (2003). Practical English language teaching. New York: McGraw-Hill. Press.

Purpura, J. (2004). Assessing Grammar. Cambridge: Cambridge University Press.

Redmond, M.V. \& Vrchota, D. (2007). Everyday Public Speaking. England: Pearson Education.

Richard, J.C. \& Schmidt, R. (Eds.). (2002). Longman Dictionary of Language. New York: Routledge.

Roohani, A. (2009). The study of emotional intelligence and literature in education; Gender and major of study. The Journal of Asian TEFL, 6(4), 33-69.

Salovey, P. \& Mayer, J.D. (1990). Emotional intelligence. Imagination, Cognition and Personality, 9, 185-211. 
Samouei, R. (2002). Interpreting and analyzing Bar-On EQ inventory. Journal of Sina Research Center, 6(2), 1-10.

Samouei, R. (2003). Azmoune houshe hayajani (Bar-On's EQ-i). Tehran:

Moasseseye Tahghighatie Olume Raftarie Sina.

Scarcella, R. C., \& Oxford, R. L. (1992). The Tapestry of Language

Learning: The Individual in the Communicative Classroom (63p.).

Boston, MA: Heinle \& Heinle.

Thoonen, E., Sleegers, P., Oort, F., Peetsma, T., \& Geijsel, F. (2011). How to improve teaching practices: the role of teacher motivation, organizational factors, and leadership practices. Educational Administration Quarterly, 47(3), 496-536. doi.10.1177/0013161X11400185

Thornbury, S. (2005). How to Teach Speaking. New York: Longman. Upadhyaya, P. (2013). A Study of the Relationship between Emotional Intelligence and Academic Achievement among Student- Teachers. European Academic Research, 1(8), 2388- 2396. Retrieved from http://euacademic.org/uploadarticle/173.pdf

Ur, P. (1996). A Course in Language Teaching: Practice and Theory. Cambridge: Cambridge.

Ur, P. (2005). Discussions that Work. Cambridge: Cambridge University Press.

Vaezi, Sh. \& Fallah, N. (2011). The relationship between Emotional Intelligence and Burnout among Iranian EFL Teachers. Journal of Language Teaching and Research, 2(5), 1122-1129.

doi:10.4304/jltr.2.5.1122-11298

Wechsler, D. (1940). Nonintellective factors in general intelligence.

Psychological Bulletin, 37, 444-445. 
REMIE - Multidisciplinary Journal of Educational Research, 8(2) 179

Karim Shabani is an assistant professor at English Department of Allameh Mohaddes Nouri University. Islamic Republic of Iran. https://orcid.org/0000-0002-1574-1122

Arezu Ghodrati is an MA graduate of TEFL at English Department of Allameh Mohaddes Nouri University. Islamic Republic of Iran.

Contact Address: Allameh Mohaddes Nouri University, Sheikh Fazlollah Nouri Street, 46418-59558. Islamic Republic of Iran

Phone: +989113954613

E-mail: k.shabani@mohaddes.ac.ir or shabanikarim@gmail.com 